\title{
Sampling a biodiversity hotspot: the orchid-bee fauna (Hymenoptera: Apidae) of Tarapoto, northeastern Peru, the richest and most diverse site of the Neotropics
}

\author{
Nemésio, $A{ }^{a *}$, Rasmussen, $C .^{b}$ \\ anstituto de Biologia, Universidade Federal de Uberlândia - UFU, Rua Ceará, s/n, Campus Umuarama, \\ CEP 38.400-902, Uberlândia, MG, Brazil \\ ${ }^{b}$ Department of Boscience, Aarhus University - AU, Ny Munkegade 114, Bldg. 1540, DK-8000 Aarhus C, Denmark \\ *e-mail: andre.nemesio@gmail.com
}

Received: September 18, 2012 - Accepted: May 27, 2013 - Distributed: November 30, 2014

(With 3 figures)

\begin{abstract}
The orchid-bee fauna of the region of Tarapoto, northeastern Peru, was surveyed using seventeen different scents as baits to attract orchid-bee males. Six hundred and fifty-nine males belonging to 41 species were actively collected with insect nets during 120 hours in late July and early August, 2012. Euglossa dressleri Moure, 1968, Euglossa laurensi Bembé, 2008, and Euglossa maculilabris Moure, 1968, three species belonging to the Euglossa cybelia species-group, are here reported for Peru for the first time. Previous sporadic and unpublished samplings in the area recorded eleven additional species. With 53 species, the region of Tarapoto can be considered the richest single site in the Neotropics for orchid bees. Diversity, estimated with the Shannon-Wiener diversity index $\left(H^{\prime}=3.02\right)$, was also the highest ever recorded for orchid bees.
\end{abstract}

Keywords: Amazon Basin, euglossina, Euglossini, euglossine bees, Hexapoda.

\section{Amostrando um 'hotspot' de biodiversidade: a fauna de abelhas-das-orquídeas (Hymenoptera: Apidae) de Tarapoto, nordeste do Peru, a área mais rica e diversa da região Neotropical}

\section{Resumo}

A fauna de abelhas euglossinas da região de Tarapoto, nordeste do Peru, foi amostrada com o uso de dezessete diferentes iscas aromáticas para atrair machos dessas abelhas. Seiscentos e cinquenta e nove machos pertencentes a 41 espécies foram coletados com rede entomológica durante 120 horas de amostragem no final de julho e início de agosto de 2012. Euglossa dressleri Moure, 1968, Euglossa laurensi Bembé, 2008, e Euglossa maculilabris Moure, 1968, três espécies pertencentes ao grupo Euglossa cybelia, foram registradas para o Peru pela primeira vez. Amostragens esporádicas prévias na área, não publicadas, registraram a ocorrência de doze espécies adicionais, não amostradas no presente estudo. Com 53 espécies registradas, a região de Tarapoto torna-se a área mais rica conhecida em abelhas euglossinas em toda a região Neotropical. A diversidade, estimada pelo índice de diversidade de Shannon-Wiener $\left(H^{\prime}=3,02\right)$, é também a mais alta já registrada para esse grupo de abelhas.

Palavras-chave: Amazônia, euglossina, Euglossini, abelhas euglossinas, Hexapoda.

\section{Introduction}

Orchid bees (Hymenoptera: Apidae: Euglossina) are important pollinators in Neotropical forests and considered to be key organisms in the ecosystems where they live (reviewed by Dressler (1982a)). These bees have become a favourite in ecological bee studies (e.g. Nemésio and Silveira, 2006b, 2007a, 2010; Rasmussen, 2009; Abrahamczyk et al., 2011) due to the ease of collecting their males, which are strongly and readily attracted to synthetic aromatic scents that mimic natural floral fragrances (Vogel, 1966; Dodson et al., 1969).
Although many orchid-bee samplings have been carried out in Peru and around $10 \%$ of all valid orchid-bee species have Peru as their type locality (see Nemésio and Rasmussen, 2011), there are only four published surveys of orchid-bee fauna in Peruvian territory, all carried out in lowland areas in the Amazon Basin (Pearson and Dressler, 1985; Bembé, 2002; Rasmussen, 2009; Abrahamczyk et al., 2011).

The region of Tarapoto, Department of San Martín, northeastern Peru (Figure 1), is of particular interest due to its singular location, exactly in the transition between 


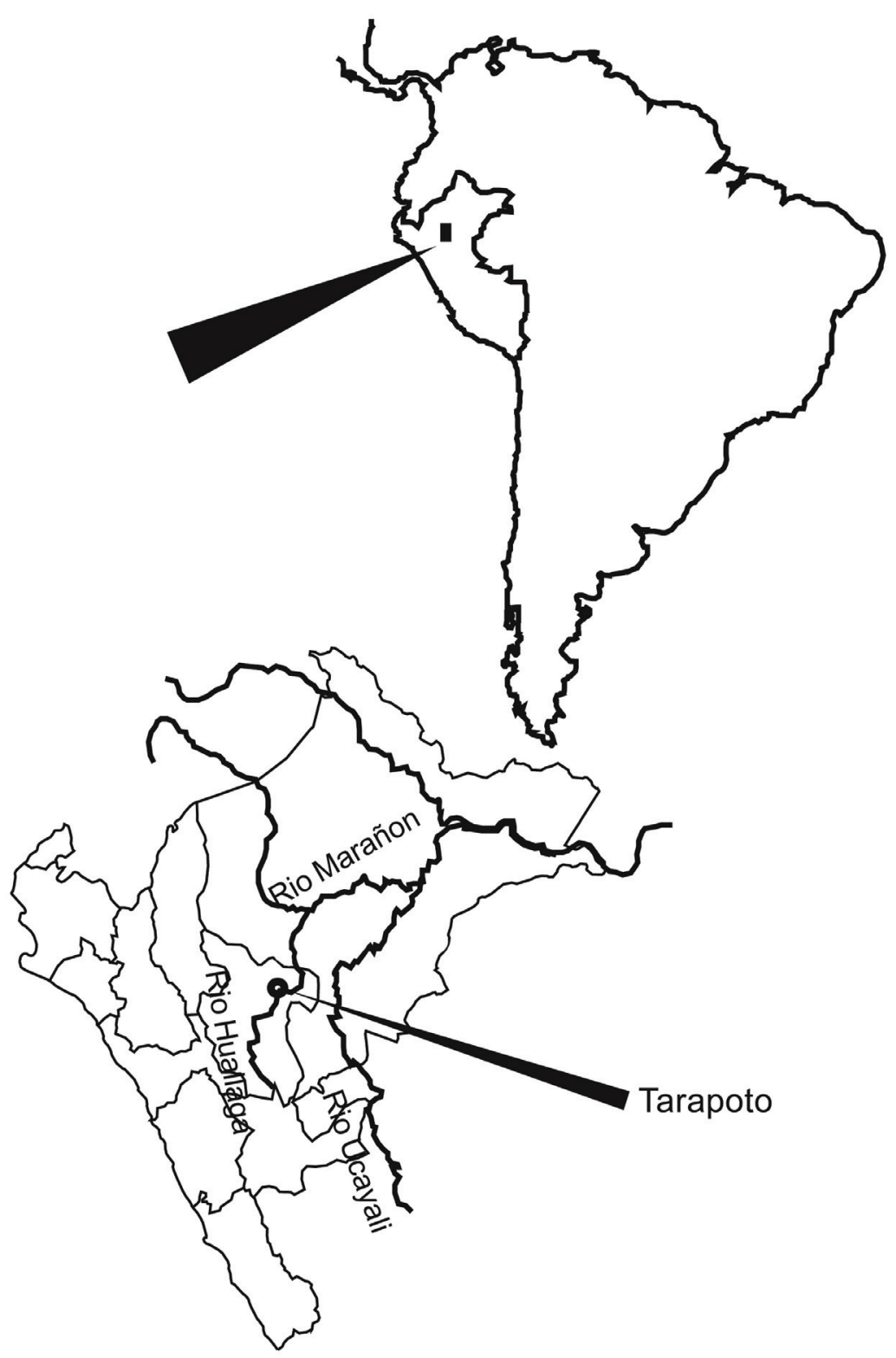

Figure 1. Map of Peru showing the location of Tarapoto.

lowland rainforest and lower montane rain forest, or cloud forest in Peru. The high precipitation associated with the abrupt elevation gradient in the region of the 'Cordillera Escalera' results in great environmental heterogeneity and a consequent unique biological diversity (Gallusser, 2002; Rasmussen, 2009). Data on the orchid-bee fauna of Tarapoto is available only from a single day of collecting, when 92 specimens belonging to 26 species were recorded (Abrahamczyk et al., 2011). This high richness revealed through a single-day survey, in addition to the fact that at least one rare and apparently geographically-restricted species has been described from the region (Rasmussen and Skov, 2006), suggested that the region of Tarapoto deserved further attention concerning its orchid-bee fauna.
The main goal of this study was to survey the orchid-bee fauna of the region of Tarapoto at an elevation gradient, focusing on the best preserved forest patches situated towards the higher parts of the 'Cordillera Escalera'.

\section{Material and Methods}

\subsection{Study sites}

This study was conducted in forest patches at different elevations at the 'Cordillera Escalera', northeast of Tarapoto in the province and department of San Martín, northeastern Peru (Figure 1). Six sites were selected from $400 \mathrm{~m}$ to $1,000 \mathrm{~m}$ a.s.1. Samplings were carried out from July $20^{\text {th }}$ to August 1' 2012. 


\subsection{Sampling}

Twenty hours of active sampling with insect nets were performed at each of the six selected sites in the areas, totalling 120 hours of field work, following the protocol established and discussed by Nemésio (2010, 2011a, b). The six sampling sites were: site- $1\left(06^{\circ} 28^{\prime} 37^{\prime \prime} \mathrm{S}, 76^{\circ} 21^{\prime} 18^{\prime \prime} \mathrm{W}\right.$, ca. $400 \mathrm{~m}$ a.s.1.), site-2 (06 $27^{\prime} 06^{\prime}$ 'S, $76^{\circ} 20^{\prime} 48^{\prime \prime} \mathrm{W}, c a$. $500 \mathrm{~m}$ a.s.1.), site-3 ( $06^{\circ} 27^{\prime} 36^{\prime}$ 'S, $76^{\circ} 20^{\prime} 03^{\prime \prime} \mathrm{W}, \mathrm{ca} .800 \mathrm{~m}$ a.s.1.), site-4 (06 $27^{\circ} 211^{\prime \prime} \mathrm{S}, 76^{\circ} 19^{\prime} 54^{\prime \prime} \mathrm{W}, c a .900 \mathrm{~m}$ a.s.1.), site-5 (06 $27^{\prime} 52^{\prime}$ 'S, $76^{\circ} 17^{\prime} 17^{\prime \prime} \mathrm{W}, c a$. $1,000 \mathrm{~m}$ a.s.l.), and site-6 $\left(06^{\circ} 27^{\prime} 45^{\prime}\right.$ 'S, $76^{\circ} 17^{\prime} 20^{\prime \prime} \mathrm{W}$, c ca. $1,000 \mathrm{~m}$ a.s.1.). Site-1 was located in an open area, close to the town of Tarapoto; all the remaining sites were located in forest patches, but site- 5 was located at the edge of the forest near a road, whereas the other sites were situated inside the forest. Vegetation at sites 2, 5 and 6 was the best preserved in the region, whereas at sites 3 and 4 it had experienced stronger anthropogenic pressures. The maximum distance among all sites was about $8 \mathrm{~km}$. At each site, 17 different scent baits were placed $c a .2 .0 \mathrm{~m}$ apart from each other at about $1.5 \mathrm{~m}$ above the ground. These baits were made of cotton wadding soaked with one of the following substances, known or believed to be attractive to orchid bees: benzyl acetate, benzyl alcohol, $r$-carvone, 1,8-cineole, $p$-cresol acetate, dimethoxybenzene, eugenol, $\beta$-ionone, methyl benzoate, methyl trans-cinnamate, heneicosane, linalool, methyl salicylate, skatole, tricosane, $p$-tolyl acetate, vanillin. Baits with cineole, the most volatile compound, were recharged every hour. Bees arriving on the baits during the sampling period were collected with insect nets and killed with ethyl acetate and pinned for posterior identification. At site-5 some Anthurium sp. (Araceae) were flowering and attracting different species of orchid bees next to the baiting station. All specimens attracted to Anthurium flowers were also collected. Additionally, site-6 was sampled by one of us (CR) from April 2002 to April 2003 once a month (from $08: 45 \mathrm{~h}$ to $12: 45 \mathrm{~h}$ ) with five attractive scents ( 1,8 cineole, benzyl acetate, eugenol, methyl salicylate, and vanillin) used to attract orchid-bee males that were actively collected with an insect net.

\subsection{Data analysis}

Diversity was estimated with the Shannon-Wiener diversity index $\left(H^{\prime}\right)$, as $H^{\prime}=-\Sigma p_{i} \ln \left(p_{i}\right)$, where $p_{i}$ is the proportion of total number of species made up of the ith species (Pielou, 1975). Evenness (E) was estimated through the formula $E=H^{\prime} / \ln (S)$, where $S$ is the species richness. Spearman rank correlation tests were used to estimate the effect of altitude on bee richness and diversity. The similarity in faunistic composition among all six sites was estimated by the similarity index of Morisita, recommended by Wolda (1981) for small samples. Similarity indexes that take into account not only presence of species, but also their relative abundances, are strongly recommended by Balmer (2002) since theoretically they better reflect natural processes. Based on those similarities, the areas were grouped using UPGMA (Sneath and Sokal, 1973). Only the collections carried out in 2012 were considered for the above analyses since they were performed under the same protocol. Similarity was also estimated for Peru as a whole (Morisita index and resulting similarities grouped using UPGMA). Data from the six sites sampled in this study in Tarapoto were merged and then compared to previous samplings carried out in Peru for which data on the relative abundance of each species was available. We used data from 13 sites: Tambopata Reserve, Madre de Dios, (Pearson and Dressler, 1985), Iquitos (Rasmussen, 2009) and Nanay, Tapiche river region (two sites), Moyobamba, Contamana, Pijuayal, Panguana, Cicra, Puerto Maldonado, and Tarapoto (Abrahamczyk et al., 2011). Since there were two samplings for Tarapoto (ours and that by Abrahamczyk and colleagues), we carried out three analyses: one including our data for Tarapoto, the second including Abrahamczyk and colleagues' (2011) data for Tarapoto, and the last one including both sets.

\subsection{Taxonomy}

Taxonomy follows Nemésio and Rasmussen (2011) with the additions provided by Hinojosa-Díaz \& Engel (2011a, b).

\section{Results}

Six hundred and fifty-nine orchid-bee males belonging to 41 species were collected in all six sites in 2012 (Table 1), whereas 28 species were collected at site-6 from 2002 to 2003 (Table 2). Data on abundance and, consequently, diversity and evenness were only available for the collections carried out in 2012. Richness, diversity and evenness were the lowest at the site situated at the lowest elevation and closer to the urban area, and were the highest at the sites situated at the highest elevation and best preserved vegetation (Table 1). No correlation was found between elevation and richness or diversity, even excluding site1 , the most distinctive of all and located outside forested areas. A positive correlation, however, was found between elevation and abundance $\left(\mathrm{r}_{\mathrm{s}}=0.83, \mathrm{P}<0.05\right)$.

Eulaema nigrita Lepeletier, 1841 was the most common species in the region, but its dominance is strongly based on its abundance at site- 1 , where it represented more than $50 \%$ of the collected specimens. Euglossa orellana Roubik, 2004a was the most common species at sites 3 and 6, Euglossa ignita Smith, 1874 was the dominant species at site 2, Euglossa imperialis Cockerell, 1922 was the most common species at site 4, and three species, Eulaema marcii Nemésio, 2009, Euglossa amazonica Dressler, 1982d, and El. nigrita were the most common species at site 5 (see Table 1). Three specimens of Eulaema tenuifasciata (Friese, 1925), two of El. meriana (Olivier, 1789), one of El. peruviana (Friese, 1903), and one of Eg. ignita were attracted to and collected on Anthurium flowers.

Seven species collected in 2002 and 2003 were not collected in 2012: Eufriesea ornata (Mocsáry, 1896) [on baits], Ef. superba (Hoffmannsegg, 1897) [on baits], Ef. surinamensis (Linnaeus, 1758) [on flowers], Euglossa cognata Moure, 1970 [on baits], Euglossa crassipunctata Moure, 1968 [on baits], Euglossa parvula Dressler, 1982c 
Table 1. Diversity, evenness, species richness and number of specimens of each orchid-bee species collected at six sampling sites near Tarapoto, Department of San Martín, northeastern Peru, after 20 hours of sampling in each site. See text for location of each site.

Sites (elevation)

\begin{tabular}{ccccccc} 
Site 1 & Site 2 & Site 3 & Site 4 & Site 5 & Site 6 & Total \\
$(\mathbf{4 0 0 ~} \mathrm{m})$ & $(\mathbf{5 5 0} \mathrm{m})$ & $(\mathbf{8 0 0} \mathrm{m})$ & $(\mathbf{9 0 0} \mathrm{m})$ & $(\mathbf{1 0 0 0} \mathrm{m})$ & $(\mathbf{1 0 0 0} \mathrm{m})$ & \\
\hline
\end{tabular}

Species

Aglae caerulea Lepeletier and Serville, 1825

$\begin{array}{llll}0 & 1 & 5 & 2 \\ 0 & 0 & 0 & 0 \\ 0 & 0 & 0 & 0\end{array}$

Eufriesea chrysopyga (Mocsáry, 1898)

Ef. magrettii (Friese, 1899)

Ef. pulchra (Smith, 1854)

Euglossa allosticta Moure, 1969

Eg. amazonica Dressler, 1982d

Eg. analis Westwood, 1840

Eg. augaspis Dressler, 1982c

Eg. bidentata Dressler, 1982b

Eg. decorata Smith, 1874

Eg. despecta Moure, 1968

Eg. dressleri Moure, 1968

Eg. hemichlora Cockerell, 1917

Eg. ignita Smith, 1874

Eg. imperialis Cockerell, 1922

Eg. intersecta Latreille, 1817

Eg. ioprosopa Dressler, 1982b

Eg. iopyrrha Dressler, 1982b

Eg. laurensi Bembé, 2008

Eg. maculilabris Moure, 1968

Eg. magnipes Dressler, 1982d

Eg. mixta Friese, 1899

Eg. mourei Dressler, 1982d

Eg. occidentalis Roubik, 2004b

Eg. orellana Roubik, 2004b

Eg. retroviridis Dressler, 1982b

Eg. rufipes Rasmussen and Skov, 2006

Eg. rugilabris Moure, 1969

Eg. securigera Dressler, 1982d

Eg. williamsi Hinojosa-Díaz and Engel, 2011b

Euglossa sp. 1

Euglossa sp. 2

Eulaema bombiformis (Packard, 1869)

El. marcii Nemésio, 2009

El. meriana (Olivier, 1789)

El. mocsaryi (Friese, 1899)

El. nigrita Lepeletier, 1841

El. peruviana (Friese, 1903)

El. tenuifasciata (Friese, 1925)

Exaerete frontalis (Guérin-Méneville, 1844)

Ex. smaragdina (Guérin-Méneville, 1844)

Total

Richness

Shannon

0

0

0

0

1

0

3
0

0

1

0
7

7
0

0

(0)

0

(0)

0

0

1

0

$\begin{array}{ll}3 & 0 \\ 0 & 1\end{array}$

$\begin{array}{lll}0 & 11 & 18\end{array}$

$\begin{array}{ccccccc}0 & 0 & 0 & 0 & 1 & 0 & 1 \\ 0 & 0 & 0 & 0 & 2 & 15 & 17 \\ 0 & 2 & 2 & 2 & 0 & 0 & 6\end{array}$

$\begin{array}{lllllll}0 & 2 & 2 & 2 & 0 & 0 & 6\end{array}$

$\begin{array}{lllllll}2 & 0 & 0 & 5 & 5 & 1 & 13\end{array}$

$\begin{array}{ccccccc}2 & 0 & 0 & 5 & 5 & 1 & 13 \\ 0 & 0 & 0 & 0 & 0 & 1 & 1 \\ 0 & 0 & 0 & 0 & 13 & 11 & 24\end{array}$

$\begin{array}{ccccccc}0 & 0 & 0 & 0 & 0 & 1 & 1 \\ 0 & 0 & 0 & 0 & 13 & 11 & 24 \\ 0 & 0 & 0 & 0 & 0 & 1 & 1\end{array}$

$\begin{array}{ccccccc}0 & 0 & 0 & 0 & 13 & 11 & 24 \\ 0 & 0 & 0 & 0 & 0 & 1 & 1\end{array}$

$\begin{array}{lllllll}0 & 0 & 1 & 3 & 1 & 1 & 6\end{array}$

$\begin{array}{llllcll}4 & 2 & 2 & 1 & 1 & 1 & 6\end{array}$

$\begin{array}{ccccccc}4 & 2 & 2 & 1 & 19 & 4 & 32 \\ 3 & 5 & 4 & 2 & 10 & 10 & 34\end{array}$

$\begin{array}{cccc}0 & 1 & 1 & 0 \\ 39 & 7 & 6 & 19\end{array}$

100

$\begin{array}{llll}1 & 0 & 0 & 0 \\ 0 & 0 & 0 & 0 \\ 0 & 2 & 2 & 0\end{array}$

$\begin{array}{lll}0 & 2 & 2 \\ 7 & 1 & 0\end{array}$

$\begin{array}{ccc}7 & 1 & 0 \\ 75 & 79 & 71\end{array}$

$\begin{array}{cccc}75 & 79 & 71 & 95 \\ 13 & 23 & 19 & 21 \\ 1.78 & 2.62 & 2.52 & 2.48\end{array}$

Evenness

$0.69 \quad 0.83$

0.85

0

$19 \quad 16$

0

0

$\begin{array}{llll}0 & 2 & 0 & 6 \\ 0 & 0 & 0 & 8\end{array}$

$\begin{array}{cccc}0 & 0 & 0 & 8 \\ 95 & 162 & 177 & 659 \\ 21 & 27 & 24 & 41\end{array}$

$\begin{array}{llll}2.48 & 2.89 & 2.6 & 3.02\end{array}$

$\begin{array}{llll}0.82 & 0.88 & 0.82 & 0.81\end{array}$


Table 2. List of orchid-bee species collected in the region of Tarapoto from April, 2002 to April, 2003.

\begin{tabular}{l} 
Aglae caerulea \\
Eufriesea magrettii (Friese, 1899) \\
Ef. ornata (Mocsáry, 1896) \\
Ef. pulchra \\
Ef. superba (Hoffmannsegg, 1817) \\
Ef. surinamensis (Linnaeus, 17580 \\
Eg. analis \\
Eg. augaspis \\
Eg. bidentata \\
Eg. cognata Moure, 1968 \\
Eg. crassipunctata Moure, 1968 \\
Eg. decorata \\
Eg. hemichlora \\
Eg. ignita \\
Eg. imperialis \\
Eg. intersecta \\
Eg. ioprosopa \\
Eg. magnipes \\
Eg. mixta \\
Eg. parvula Dressler, 1982c \\
Eulaema bombiformis \\
El. marcii \\
El. meriana \\
El. mocsaryi \\
El. nigrita \\
El. peruviana \\
El. polyzona (Mocsáry, 1897) \\
El. tenuifasciata \\
Exaerete frontalis \\
\hline
\end{tabular}

[on baits], Eulaema polyzona (Mocsáry, 1897) [on mud], and Exaerete dentata (Linnaeus, 1758) [on flowers]. Moreover, four additional species were recorded by Abrahamczyk et al. (2011) for Tarapoto but not collected in the present study: Eufriesea purpurata (Mocsáry, 1896), Euglossa laevicincta Dressler, 1982c, Euglossa modestior Dressler, 1982d, and Eulaema cingulata (Fabricius, 1804) - this latter species listed as El. pseudocingulata Oliveira, 2006, a junior synonym according to Nemésio and Rasmussen (2011).

Fifteen out of the 17 scent baits were attractive to male orchid bees (Tables 3, 4). Only linalool and tricosane were not attractive. Eight scents (Table 3) attracted more than 10 specimens, and cineole, skatole, vanillin, methyl salicylate, methyl trans-cinnamate and eugenol were the six most powerful attractants in Tarapoto, responding for $90 \%$ of all collected specimens (Table 3). Methyl trans-cinnamate, skatole and methyl salicylate attracted the highest number of species (15), followed by cineole and vanillin (13 species each) (Table 3). Thirteen species were exclusively attracted to one specific scent, but eight of them were represented by singletons. Only five species represented by more than one specimen were exclusively attracted to one scent: all six Euglossa rugilabris Moure, 1967 were attracted by cineole; all two Euglossa maculilabris Moure, 1965 and all seven Euglossa bidentata Dressler, 1982b were only attracted by skatole, and all three Euglossa decorata Smith, 1874 and all ten Euglossa magnipes Dressler, $1982 \mathrm{~d}$ were attracted by vanillin (Tables 3, 4). Only one species (Euglossa sp. 2) was only attracted to a lesser (weak attractive) scent ( $\beta$-ionone, Table 4).

The ordination of the sites according to the similarity of their faunas showed medium to high overall $(55 \%$ to $86 \%$ ) values among the five forest areas and a relatively very low (34\%) value between these areas and the open area situated at the lowest elevation (see Figure 2).

When the samplings from Peru were compared, the local fauna of Tarapoto recorded in the present study showed to be close to no particular area, sharing only ca. $45 \%$ percent of similarity with all other areas, except the two sites close to the Tapiche river, Loreto, NE Peru, which shared about $35 \%$ similarity with all other Peruvian areas, Tarapoto included (Figure 3a). The situation is almost identical when data from Tarapoto was extracted from Abrahamczyk et al. (2011), the only difference being the value of similarity shared between Tarapoto and the remaining sites, which was slightly lower (Figure $3 b$ ). When both datasets from Tarapoto were included in the analysis, they revealed to be the most similar to each other, sharing about $42 \%$ of similarity with the remaining sites, except for the sites close to the Tapiche river (Figure 3c).

\section{Discussion}

\subsection{Faunistics, richness and diversity}

The strategy of intensive sampling, using the same protocol as employed here, over a few days during the season when orchid bees are most actively foraging, has been demonstrated to be adequate for surveys focusing on this group of bees (Nemésio, 2010, 2011a, b, Nemésio et al., 2012). In fact, some authors argue that for orchid bees, surveys of a single day have great utility, and may reveal almost as much about local community structure as studies lasting a full year (Roubik, 2004a). Indeed, the grouping of both ours and Abrahamczyk and co-workers's (2011) data on the orchid-bee fauna of Tarapoto together among more than ten areas, even with different sampling protocols, seems to corroborate this point of view.

The species richness observed in Tarapoto is astonishing and only rivalled by that observed in central Panama, where 44 species were attracted to baits and six additional ones were recorded, totalling 50 species (Ackerman, 1983). The total of 53 species observed for Tarapoto region has no parallel in the Amazon Basin. In the western Amazon of Brazil, orchid-bee samplings usually record from 16 to 38 species (Powell and Powell, 1987; Becker et al., 1991; Morato 1994; Oliveira and Campos, 1996; Nemésio and Morato, 2004, 2006; Storck-Tonon et al., 2009, 2011) and even in the Peruvian Amazon, the highest richness ever recorded was that of the Tambopata Reserve, with 39 
Table 3. Number of specimens of each orchid-bee species collected at six sampling sites near Tarapoto, Department of San Martín, northeastern Peru, after 20 hours of sampling in each site, according to scent preference (samples from all six sites pooled). $\mathrm{BA}=$ benzyl acetate; $\mathrm{TA}=p$-tolyl acetate; $\mathrm{MC}=$ methyl trans-cinnamate; $\mathrm{CI}=$ cineole; $\mathrm{VA}=$ vanillin; $\mathrm{SK}=$ skatole; $\mathrm{EU}=$ eugenol; $\mathrm{MS}=$ methyl salicylate; $\mathrm{FL}=$ flight (attracted to the area but not at any specific scent bait). NES = number of exclusive species. NES-S = number of exclusive species excluding singletons.

\begin{tabular}{|c|c|c|c|c|c|c|c|c|c|c|}
\hline Scent & $\mathbf{B A}$ & TA & MC & CI & VA & SK & $\mathbf{E U}$ & MS & FL & Total \\
\hline \multicolumn{11}{|c|}{ Species } \\
\hline Aglae caerulea & 00 & 00 & 06 & 00 & 00 & 03 & 00 & 00 & 02 & 11 \\
\hline Eufriesea chrysopyga & 00 & 00 & 00 & 01 & 00 & 00 & 00 & 00 & 00 & 01 \\
\hline Ef. magrettii & 00 & 00 & 02 & 04 & 00 & 00 & 00 & 09 & 00 & 15 \\
\hline Ef.pulchra & 00 & 00 & 00 & 00 & 00 & 00 & 00 & 01 & 00 & 01 \\
\hline Euglossa allosticta & 00 & 00 & 00 & 00 & 00 & 09 & 01 & 00 & 00 & 10 \\
\hline Eg. amazonica & 00 & 00 & 00 & 00 & 00 & 24 & 09 & 00 & 00 & 33 \\
\hline Eg. analis & 00 & 00 & 00 & 00 & 00 & 03 & 01 & 00 & 00 & 04 \\
\hline Eg. augaspis & 00 & 00 & 00 & 00 & 02 & 01 & 00 & 02 & 01 & 06 \\
\hline Eg. bidentata & 00 & 00 & 00 & 00 & 00 & 07 & 00 & 00 & 00 & 07 \\
\hline Eg. decorata & 00 & 00 & 00 & 00 & 03 & 00 & 00 & 00 & 00 & 03 \\
\hline Eg. despecta & 00 & 00 & 00 & 02 & 00 & 07 & 02 & 00 & 00 & 11 \\
\hline Eg. dressleri & 00 & 00 & 00 & 00 & 00 & 01 & 00 & 00 & 00 & 01 \\
\hline Eg. hemichlora & 00 & 00 & 00 & 00 & 00 & 00 & 00 & 01 & 00 & 01 \\
\hline Eg. ignita & 01 & 02 & 02 & 06 & 01 & 00 & 04 & 21 & 02 & 39 \\
\hline Eg. imperialis & 00 & 02 & 02 & 62 & 01 & 00 & 00 & 07 & 00 & 74 \\
\hline Eg. intersecta & 00 & 02 & 01 & 06 & 00 & 00 & 00 & 00 & 00 & 09 \\
\hline Eg. ioprosopa & 00 & 00 & 01 & 01 & 07 & 08 & 00 & 00 & 00 & 17 \\
\hline Eg. iopyrrha & 00 & 00 & 00 & 00 & 00 & 03 & 00 & 01 & 00 & 04 \\
\hline Eg. laurensi & 00 & 00 & 01 & 00 & 00 & 00 & 00 & 00 & 00 & 01 \\
\hline Eg. maculilabris & 00 & 00 & 00 & 00 & 00 & 02 & 00 & 00 & 00 & 02 \\
\hline Eg. magnipes & 00 & 00 & 00 & 00 & 10 & 00 & 00 & 00 & 00 & 10 \\
\hline Eg. mixta & 00 & 00 & 00 & 00 & 00 & 04 & 00 & 13 & 01 & 18 \\
\hline Eg. mourei & 00 & 00 & 00 & 00 & 07 & 00 & 00 & 00 & 01 & 08 \\
\hline Eg. occidentalis & 00 & 00 & 00 & 00 & 10 & 00 & 00 & 02 & 01 & 13 \\
\hline Eg. orellana & 02 & 01 & 03 & 28 & 33 & 00 & 07 & 10 & 01 & 85 \\
\hline Eg. retroviridis & 00 & 00 & 01 & 00 & 00 & 00 & 00 & 00 & 00 & 01 \\
\hline Eg. rufipes & 00 & 01 & 00 & 16 & 00 & 00 & 00 & 00 & 00 & 17 \\
\hline Eg. rugilabris & 00 & 00 & 00 & 06 & 00 & 00 & 00 & 00 & 00 & 06 \\
\hline Eg. securigera & 00 & 00 & 02 & 00 & 00 & 02 & 09 & 00 & 01 & 14 \\
\hline Eg. williamsi & 00 & 00 & 00 & 00 & 00 & 00 & 00 & 01 & 00 & 01 \\
\hline Euglossa sp. 1 & 00 & 00 & 22 & 00 & 00 & 00 & 02 & 00 & 00 & 24 \\
\hline Eulaema bombiformis & 00 & 01 & 00 & 00 & 00 & 00 & 00 & 04 & 01 & 06 \\
\hline El. marcii & 07 & 01 & 02 & 00 & 09 & 00 & 10 & 00 & 03 & 32 \\
\hline El. meriana & 01 & 01 & 03 & 00 & 06 & 01 & 00 & 15 & 00 & 27 \\
\hline El. mocsaryi & 00 & 00 & 00 & 00 & 00 & 00 & 00 & 01 & 01 & 02 \\
\hline El. nigrita & 00 & 02 & 00 & 22 & 27 & 54 & 00 & 00 & 00 & 105 \\
\hline El. peruviana & 01 & 05 & 00 & 00 & 00 & 00 & 00 & 00 & 00 & 06 \\
\hline El. tenuifasciata & 00 & 00 & 00 & 00 & 00 & 00 & 00 & 00 & 01 & 01 \\
\hline Exaerete frontalis & 00 & 00 & 02 & 02 & 00 & 00 & 01 & 01 & 00 & 06 \\
\hline Ex. smaragdina & 00 & 00 & 01 & 01 & 06 & 00 & 00 & 00 & 00 & 08 \\
\hline Total of specimens & 12 & 18 & 51 & 157 & 122 & 129 & 46 & 89 & 16 & 639 \\
\hline No. of species & 05 & 10 & 15 & 13 & 13 & 15 & 10 & 15 & 12 & 39 \\
\hline NES & 00 & 00 & 02 & 02 & 02 & 03 & 00 & 03 & $00 *$ & \\
\hline NES-S & 00 & 00 & 00 & 01 & 02 & 02 & 00 & 00 & 00 & \\
\hline
\end{tabular}

Eulaema tenuifasciata was not attracted to any specific scent bait. One specimen was collected flying around the bait station and two additional specimens were collected on Anthurium sp. flowers (see Table 4). 
Table 4. Number of specimens of each orchid-bee species collected at six sampling sites near Tarapoto, Department of San Martín, northeastern Peru, after 20 hours of sampling in each site, according to scent preference (samples from all six sites pooled). $\mathrm{BA}=$ benzyl alcohol; $\mathrm{BI}=\beta$-ionone; $\mathrm{CA}=r$-carvone; $\mathrm{CR}=p$-cresol acetate; $\mathrm{DB}=$ dimethoxibenzene; $\mathrm{HE}=$ heneicosane; $\mathrm{MB}=$ methyl benzoate; $\mathrm{FO}=$ on flower (Anthurium $\mathrm{sp}$.).

\begin{tabular}{|c|c|c|c|c|c|c|c|c|c|}
\hline Scent & BA & BI & $\mathbf{C A}$ & $\mathbf{C R}$ & DB & MB & HE & FO & Total \\
\hline \multicolumn{10}{|c|}{ Species } \\
\hline Euglossa amazonica & 01 & 00 & 00 & 00 & 00 & 00 & 00 & 00 & 01 \\
\hline Eg. augaspis & 00 & 00 & 00 & 00 & 01 & 00 & 00 & 00 & 01 \\
\hline Eg. ignita & 01 & 00 & 00 & 00 & 00 & 00 & 00 & 01 & 02 \\
\hline Eg. intersecta & 00 & 01 & 00 & 00 & 00 & 00 & 00 & 00 & 01 \\
\hline Eg. orellana & 00 & 00 & 02 & 01 & 00 & 01 & 01 & 00 & 05 \\
\hline Euglossa sp. 2 & 00 & 01 & 00 & 00 & 00 & 00 & 00 & 00 & 01 \\
\hline Eulaema meriana & 01 & 01 & 00 & 00 & 00 & 00 & 00 & 01 & 03 \\
\hline El. peruviana & 01 & 00 & 00 & 00 & 00 & 00 & 00 & 03 & 04 \\
\hline El. tenuifasciata & 00 & 00 & 00 & 00 & 00 & 00 & 00 & 02 & 02 \\
\hline Total & 04 & 03 & 02 & 01 & 01 & 01 & 01 & 07 & 20 \\
\hline No. of species & 04 & 03 & 01 & 01 & 01 & 01 & 01 & 04 & 09 \\
\hline
\end{tabular}

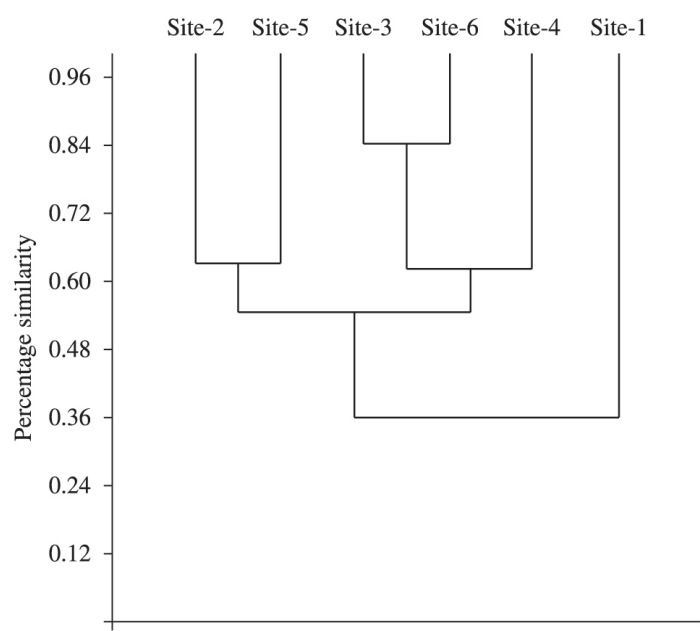

Figure 2. Clustering of the six areas at Tarapoto region according to their similarity.

species (Dressler, 1985; Pearson and Dressler, 1985). Other authors recorded 33 species for Huánuco (Bembé, 2002) and Iquitos (Rasmussen, 2009) regions, and Abrahamczyk et al. (2011) recorded from 16 to 27 species in 10 different sites in eastern Peru. Also, the diversity recorded for Tarapoto, as estimated with the Shannon-Wiener diversity index $\left(\mathrm{H}^{\prime}=3.02\right)$, is the highest ever observed for orchid bees all over the Neotropics.

The high proportion of species represented by singletons in each of the six sites, and even when all six sites are considered together (Table 1), though, suggests that the orchid-bee fauna of Tarapoto may have been undersampled (see Coddington et al., 2009). In fact, previous samplings in the area by one of us (CR) and the one-day sampling carried out by Abrahamczyk et al. (2011) revealed eleven additional species not recorded in the present study. Ad hoc explanations for their absence can be argued for some, but not for all missing species. Species of Eufriesea Cockerell,
1908 are highly seasonal (see Kimsey, 1982) and since the collections in 2012 were carried out during a short period of time, the most probable explanation for the absence of Ef. ornata, Ef. purpurata, Ef. superba and Ef. surinamensis is that adults were not active in late July and early August, 2012. Exaerete dentata is usually not attracted to the scents ordinarily used as baits (see Nemésio and Silveira, 2006a), as well as El. polyzona. Although widely distributed throughout the Amazon, Eg. cognata and Eg. parvula are not common species in orchid-bee samplings, which might explain our failure in recording them in our 2012 survey. Euglossa laevicincta, Eg. modestior and El. cingulata were singletons in Abrahamczyk et al.'s (2011) sampling. These may be rare local species and were not detected in our samplings, although E. laevicincta was also reported from Tarapoto by Ramirez et al. (2010). Finally, we cannot explain the absence of Eg. crassipunctata during the collections carried out in 2012, since it is a species relatively common where it does occur. It should be emphasised that traditional orchid-bee inventories since the early 1970's are strongly based on attracting males to scent baits. It is known, however, that some species are usually not responsive to the scents commonly used in orchid-bee studies, especially some species of Euglossa Latreille, 1802 belonging to the subgenus Euglossella Moure, 1968 (see Moure, 1996), almost all species of Eulaema Lepeletier, 1841 belonging to the Eulaema seabrai Moure, 1960 species group (see Nemésio and Silveira, 2004, 2006c, Nemésio and Ferrari, 2012), and the species of Exaerete Hoffmannsegg, 1817 belonging to the Exaerete dentata (Linnaeus, 1758) species group (see Nemésio and Silveira, 2006a). Eulaema tenuifasciata, for example, was only collected in the present study on Anthurium flowers. These constraints were recently discussed by Nemésio (2012) and alternative and complimentary sampling methods must be employed if one intends to better understand the actual richness of orchid bees in a given place. The alternative methods (e.g. collecting on flowers, searching for nests, 

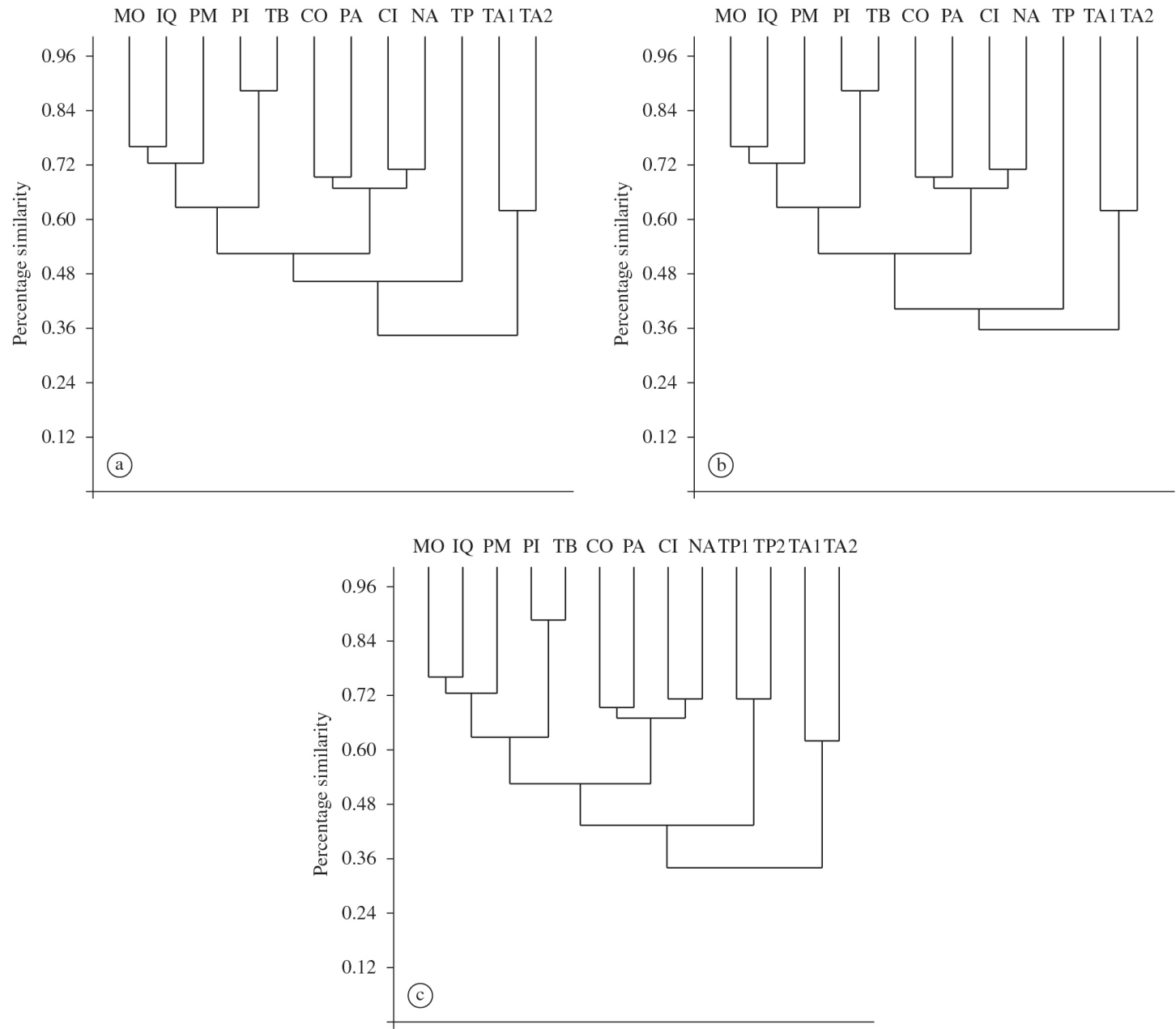

Figure 3. Clustering of Peruvian areas according to their similarity. a) including our data for Tarapoto. b) including Abrahamczyk et al.'s (2011) data for Tarapoto. c) including our (TP1) and Abrahamczyk et al.'s (2011) (TP2) data for Tarapoto. $\mathrm{NA}=$ Nanay, TA1 $=$ Tapiche $1, \mathrm{TA} 2=$ Tapiche $2, \mathrm{MO}=$ Moyobamba, $\mathrm{CO}=$ Contamana, PI $=$ Pijuayal, PA $=$ Panguana, $\mathrm{CI}=$ Cicra, $\mathrm{PM}=$ Puerto Maldonado, $\mathrm{TB}=$ Tambopata, $\mathrm{IQ}=$ Iquitos, $\mathrm{TP}=$ Tarapoto. Data from NA, TA1, TA2, MO, CO, PI, PA, CI, PM, and TP2 extracted from Abrahamczyk et al. (2011); TB from Pearson and Dressler (1985); IQ from Rasmussen (2009), TP1 (present study).

use of trap nests, among others), however, are more time consuming, usually resulting in fewer specimens and are usually neglected when samplings are carried out during a limited period of time. In these circumstances, baiting, in spite of its limitations, offers the best results (see Nemésio, 2012).

Three species deserve special attention since they were recorded for the first time in Peru and, thus, represent range extensions of their previously known geographic distributions. Euglossa maculilabris Moure, 1968 was described from Panama and had additionally only been recorded in Costa Rica, Colombia and Ecuador (by Ramírez et al., 2002). The two specimens collected at the site situated at the highest elevation in Tarapoto represent a significant extension southwards from its southernmost previously known record in Ecuador. A single male of Euglossa dressleri
Moure, 1968, also described from Panama, was recorded at the site situated at the lowest elevation in Tarapoto. This species had only been recorded in Costa Rica and Ecuador, besides the type locality (Ramírez et al., 2002). Euglossa laurensi Bembé, 2008 was recently described from Bolivia and this is the first record of this species outside Bolivia, extending its known distribution northwards. It should be pointed out that all three species mentioned above belong to the Euglossa cybelia species group, and a fourth species, Euglossa ioprosopa Dressler, 1982b, was also recorded in Tarapoto in four of the six sampled sites (Table 1).

Also, a single male of Euglossa retroviridis Dressler, $1982 \mathrm{~b}$, was recorded in the present study and it is the second specimen belonging to this species ever recorded in Peru - the other one recently reported by Abrahamczyk et al. (2011) from Nanay, Loreto. Finally, a single male highly 
similar to the recently described Euglossa williamsi Hinojosa-Díaz and Engel, 2011b was collected in the present study. This species was described based on only two specimens, one from Ecuador and the other one from central Peru. The specimen collected in Tarapoto is midway between both previously known geographic sites where this species is known to occur. Although this particular specimen has wider paraocular ivory markings than the other two known specimens (see Hinojosa-Díaz and Engel, 2011b), we consider it as just an intra-specific variation since it matched the original description in all other characters. Of course, larger series are necessary to understand the range of variations in this species and to be confident of the identity of our specimen.

The high richness here observed for orchid bees in Tarapoto is not entirely surprising, since the same phenomenon has already been recorded for other taxonomic groups (Davis, 1986; Dasmahapatra et al., 2010). Dasmahapatra et al. (2010) argued that the region of Tarapoto is a well-defined 'suture zone' between two areas of butterfly endemism in the lowland rainforest: the Río Mayo/upper Río Huallaga valley systems on one hand (Departments of San Martín and Huánuco), and the lower Río Huallaga and Río Ucayali regions on the other hand (Departments of San Martín, Loreto and Ucayali). These two regions are separated by the 'Cordillera Escalera', a low (mostly $<1500 \mathrm{~m}$ altitude) easternmost extension of the Andes. Suture zones of this kind (see Dasmahapatra et al., 2010 and references therein) are argued to form the meeting place for separate biotas recently expanded from refuges, here from the putative 'Huallaga' (Western) and 'Ucayali' (Eastern) Pleistocene refuges. This phenomenon could also explain, at least partially, the high richness of orchid-bee species observed in this study, as well as of other organisms in previous studies (Davis, 1986; Dasmahapatra et al., 2010). In fact, for forest taxa with a lesser dispersal ability and vagility than orchid bees, even high levels of local geographic differentiation and diversification were observed, as for butterflies of the tribe Ithomiini and the subtribe Heliconiina (Lepidoptera: Nymphalidae) (Gallusser, 2002; Dasmahapatra et al., 2010).

\subsection{Scent preferences}

The differential attractiveness of the scents used in the present study is similar to that observed in a previous study in Peru with multiple $(>10)$ scents: a few of them are highly attractive and most scents attract a low number of species and specimens (see Pearson and Dressler, 1985). It should be stressed, however, that two scents that were poorly attractive in Pearson and Dressler's (1985) study (methyl trans-cinnamate, six specimens and three species; skatole, three specimens and two species) were highly attractive in the present study (see Table 3). One possible explanation is that both scents are usually commercialised as powder. It is possible that differences in the way these scents were handled and offered to the bees respond for the astonishing differences in both studies. We dissolved the powders in common alcohol $\left(92.8^{\circ}\right)$ until saturation and then, immersed a piece of string in the resulting solutions. These strings were then placed hanging from branches in the bait station, the alcohol rapidly evaporated and they became highly attractive (vanillin was also submitted to the same procedure). This same protocol has been used by one of us in Atlantic Forest areas (eastern Brazil) with similar success (Nemésio, unpub. data). Some researchers have avoided using skatole since it does stink and its bad smell usually impregnates all field and personal equipment. Although this is true, skatole has proved to be one of the best attractants for orchid-bee males, both in this study and in surveys carried out in the Brazilian Atlantic Forest (Nemésio, unpub. data). We therefore strongly encourage its use in orchid-bee inventories, since some species are strongly attracted by skatole, and there are even those exclusively attracted by skatole at some sites (see Table 3).

Less attractive scents should also not be discarded. For example, $p$-tolyl acetate was not a major attractant in the present study, but most specimens of Eulaema peruviana were attracted by this scent. It was also one of the few scents attractive to a rare orchid-bee in the Brazilian Atlantic Forest (Nemésio et al., 2012) and should be considered in future orchid-bee studies. The same was observed by Pearson and Dressler (1985), when anysil acetate was not a major attractant, but was useful for attracting some of the rarer species at Tambopata region not attracted by any other scent.

Some closely related species apparently did not compete for the same scents in Tarapoto during this study. For example, four species of Euglossa (Glossura) showed different scent preferences: E. ignita, E. imperialis, E. occidentalis, and E. orellana (see Table 3). On the other hand, other species that are intimately related, as all Euglossa (Euglossa) belonging to the analis and cybelia species groups, showed strong preference for cineol. There is no study to date suggesting that phylogenetically closelyrelated species share preferences for the same or similar scents. This hypothesis should be further investigated.

Finally, it is outstanding the differences in scent preferences observed for the same species in the present study and that by Rasmussen (2009) in the region of Iquitos, the closest site sampled for orchid-bees which data on scent preferences are available. The area studied by Rasmussen (2009) is typical lowland Amazonian Forest, contrary to this study. Differences in natural availability of scents in both areas are here hypothesised to explain the observed differences, although it should be considered that Rasmussen (2009) only used five scents (all of them also used in the present study), and some of the most powerful attractants in the present study (e.g., skatole, methyl trans-cinnamate) were not used in Iquitos.

Based on the results here presented, we encourage researchers to use a wider array of scents, more than the usual five or six, in future orchid-bee studies to better sample those odd little-responsive species that usually escape our attention, especially in highly species-rich areas (see also Nemésio, 2012). 


\subsection{Similarity among Peruvian areas}

Similarity among orchid-bee faunas in different Peruvian areas showed no obvious pattern. Some areas in the northern portion of Peru, such as Nanay and Iquitos, grouped with southern areas, such as Cicra and Puerto Maldonado, respectively, which otherwise share few similarities regarding their phytophysiognomies. It should be emphasised, though, that available data came from studies based on different sampling protocols, using different scent baits, during different periods of time. Nemésio and Silveira (2007b) had already pointed out this kind of limitation when comparing orchid-bee faunas throughout the entire Neotropical region. Thus, more long-term studies in Peru would be important to verify the validity of the short-term studies for assessing the orchid-bee communities of all sampled areas in Peru, particularly those rapidly sampled by Abrahamczyk et al. (2011). These studies may be of importance to provide a first overall view and highlight possible hotspots for orchid bees. Nevertheless, they may also be not intensive enough to reflect the actual diversity in a given area, as pointed out by Coddington et al. (2009), and we strongly suggest that Peruvian areas should be further investigated concerning their orchid-bee faunas, given their potential to reveal new and little known species, and help us to understand the geographic distributions of many species.

\section{Acknowledgements}

INRENA kindly allowed our study in the area with a specific permit for studying the orchid-bee fauna of Tarapoto. We also thank Stephanie Gallusser and family for allowing us to sample sites 3 and 4, within their property, Paula Guardenho Maywald and Diana Pacheco Seixas for helping in field work, and Angelo B. M. Machado for partially supporting our field work.

\section{References}

ABRAHAMCZYK, S., GOTTLEUBER, P., MATAUSCHEK, C. and KESSLER, M., 2011. Diversity and community composition of euglossine bee assemblages (Hymenoptera: Apidae) in western Amazonia. Biodiversity and Conservation, vol. 20, no. 13, p. 2981-3001. http://dx.doi.org/10.1007/s10531-011-0105-1.

ACKERMAN, JD., 1983. Diversity and seasonality of male euglossine bees (Hymenoptera: Apidae) in Central Panama. Ecology, vol. 64, no. 2, p. 274-283. http://dx.doi.org/10.2307/1937075.

BALMER, O., 2002. Species lists in ecology and conservation: abundances matter. Conservation Biology, vol. 16, no. 4, p. 1160-1161. http://dx.doi.org/10.1046/j.1523-1739.2002.01568.x.

BECKER, P., MOURE, JS. and PERALTA, FJA., 1991. More about euglossine bees in Amazonian forests fragments. Biotropica, vol. 23 , no. 4 , p. 586-591. http://dx.doi.org/10.2307/2388396.

BEMBÉ, B., 2002. Prachtbienenfunde aus Panguana, Huánuco, Peru. Spixiana, vol. 25, p. 245-249.

BEMBÉ, B., 2008. Euglossa laurensi sp. n. - Eine neue Prachtbienenart aus Bolivien (Hymenoptera, Apidae, Euglossini).
Mitteilungen der Münchner Entomologischen Gesellschaft, vol. 98 , p. 59-65.

COCKERELL, TDA., 1908. Notes on the bee-genus Exaerete. Psyche, vol. 15, no. 2, p. 41-42. http://dx.doi.org/10.1155/1908/10750.

COCKERELL, TDA., 1917. Some euglossine bees. Canadian Entomologist, vol. 49, no. 4, p. 144-146. http://dx.doi.org/10.4039/ Ent49144-4.

COCKERELL, TDA., 1922. Bees in the collection of the United States Museum. Proceedings of the United States National Museum, vol. 60 , no. 18 , p. $1-20$.

CODDINGTON, JA., AGNARSSON, I., MILLER, JA., KUNTNER, M. and HORMIGA, G., 2009. Undersampling bias: the null hypothesis for singleton species in tropical arthropod surveys. Journal of Animal Ecology, vol. 78, no. 3, p. 573-584. http:// dx.doi.org/10.1111/j.1365-2656.2009.01525.x. PMid:19245379

DASMAHAPATRA, KK., LAMAS, G., SIMPSON, F. and MALLET, J., 2010. The anatomy of a 'suture zone' in Amazonian butterflies: a coalescent-based test for vicariant geographic divergence and speciation. Molecular Ecology, vol. 19, no. 19, p. 4283-4301. http://dx.doi.org/10.1111/j.1365-294X.2010.04802.x. PMid:20819158

DAVIS, TJ., 1986. Distribution and natural history of some birds from the departments of San Martín and Amazonas. The Condor, vol. 80 , p. $30-56$.

DODSON, CH., DRESSLER, RL., HILLS, HG., ADAMS, RM. and WILLIAMS, NH., 1969. Biologically active compounds in orchid fragrances. Science, vol. 164, no. 3885, p. 1243-1249. http://dx.doi.org/10.1126/science.164.3885.1243. PMid:17772561

DRESSLER, RL., 1982a. Biology of the orchid bees (Euglossini). Annual Review of Ecology and Systematics, vol. 13, no. 1, p. 373-394. http://dx.doi.org/10.1146/annurev.es.13.110182.002105.

DRESSLER, RL., 1982b. New species of Euglossa. II. (Hymenoptera: Apidae). Revista de Biologia Tropical, vol. 30, p. 121-129.

DRESSLER, RL., 1982c. New species of Euglossa. III. The bursigera species group (Hymenoptera: Apidae). Revista de Biologia Tropical, vol. 30, p. 131-140.

DRESSLER, RL., 1982d. New species of Euglossa IV. The cordata and purpurea species groups. Revista de Biologia Tropical, vol. 30, p. 141-150.

DRESSLER, RL., 1985. Euglossine bees (Hymenoptera: Apidae) of the Tambopata reserved zone, Madre de Dios, Perú. Revista Peruana de Entomología, vol. 27, p. 75-79.

FABRICIUS, JC., 1804. Systema Piezatorum secundum Ordines, Genera, Species adiectis Synonymis, Locis, Observationibus, Descriptionibus. Brunsvigae: Carolum Reichard.

FRIESE, H., 1899. Monographie der Bienengattung Euglossa Latr. Természetrajzi Füzetek, vol. 22, p. 117-172.

FRIESE, H., 1903. Nachtrag zur Monographie der Bienengattung Euglossa. Annales Historico-Naturales Musei Nationalis Hungarici, vol. 1, p. 574-575. [Természettudományi Múzeum évkönyve]

FRIESE, H., 1925. Neue neotropischen Bienenarten, zugleich II. Nachtrag zur Bienenfauna von Costa Rica (Hym.). Stettiner Entomologische Zeitung, vol. 86, p. 1-41.

GALLUSSER, SA., 2002. Biology, behaviour and taxonomy of two Oleria onega subspecies (Ithomiinae, Nymphalidae, 
Lepidoptera) in north-eastern Peru. Neuchâtel: Universitè de Neuchâtel. 115 p. Ph.D. Thesis.

GUÉRIN-MENÉVILLE, FE., 1844. Iconographie du règne animal de G. Cuvier ou représentation d'après nature de l'une des espèces les plus remarquables, et souvent non encore figurées, de chaque genre d'animaux. Paris: J. B. Baillière. vol. 3.

HINOJOSA-DÍAZ, IA. and ENGEL, MS., 2011a. Revision of the orchid bee subgenus Euglossella (Hymenoptera, Apidae), Part I, The decorata species group. ZooKeys, vol. 140, p. 27-69. http://dx.doi.org/10.3897/zookeys.140.1923. PMid:22144858

HINOJOSA-DÍAZ, IA. and ENGEL, MS., 2011b. Euglossa williamsi, a new species of orchid bee from the Amazon Basin of Ecuador and Peru, with notes on its taxonomic association and biogeography (Hymenoptera, Apidae). ZooKeys, vol. 159, p. 4963. http://dx.doi.org/10.3897/zookeys.159.2239. PMid:22303114

HOFFMANNSEGG, JC., 1817. Entomologische Bemerkungen bei Gelegenheit der Abhandlungen über amerikanische Insecten, in der vierten bis sechsten Lieferung von den Recueils d'observations de Zoologie et d'Anatomie comparée, oder dem 2ten Theile der Reise, der Herren Al. v. Humboldt und A. Bonpland, nemlich: No. IX. in Livr. 4. p. 197-283 und No. XI. XII. in Livr. 5. 6. p. 294-397. Zoologisches Magazin, vol. 1, n. 1, p. 8-56.

KIMSEY, LS., 1982. Systematics of bees of the genus Eufriesea (Hymenoptera, Apidae). University of California Publications in Entomology, vol. 95, p. 1-125.

LATREILLE, PA., 1802. Histoire naturelle générale et particulière des Crustacés et des Insectes. Ouvrage faisant suite à l'Histoire Naturelle générale et particulière, composée par Leclercq de Buffon, et rédigée par C.S. Sonnini, membre de plusiers Sociétés savantes. Paris: F. Dufart. 467 p. vol. 3.

LATREILLE, PA., 1817. Euglosse. In North Carolina State University (Ed.). Nouveau dictionnaire d'histoire naturelle, appliquée aux arts, à l'agriculture, à l'économie rurale et domestique, à la médecine, etc. Paris: Déterville. p. 533-535. vol. 10.

LEPELETIER DE SAINT FARGEAU, ALM., 1841. Histoire Naturelle des Insectes, Hyménoptères. Paris: Librairie Encyclopédique de Roret. 680 p. vol. 2.

LEPELETIER DE SAINT FARGEAU, ALM. and AUDINETSERVILLE, JG., 1825-1828. In LATREILLE, PA. (Ed.). Encyclopédie méthodique ou par ordre des matières. Histoire naturelle. Entomologie, ou histoire naturelle des crustacés, des arachnides et des insectes. Paris: Veuve Agasse. p. 1-832. (1825) 1-344, (1828) 345-832.

LINNAEUS, C., 1758. Systema Naturae per Regna tria Naturae, secundum Classes, Ordines, Genera, Species, cum Charateri-bus, Differentiis, Synonymis, Locis. Tomus I. Editio Decima Reformata. Stockholm: Laurentii Salvii. 823 p.

MOCSÁRY, A., 1896. Species Hymenopterorum magnificæ novæ in collectione musæi nationalis Hungarici. Természetrajzi Füzetek, vol. 19, p. 1-8.

MOCSÁRY, A., 1897. Species septem novæ generis Euglossa Latr. in collectione musaei nationalis Hungarici. Természetrajzi Füzetek, vol. 20, p. 442-446.

MOCSÁRY, A., 1898. Species novae generum: Euglossa Latr. et Epicharis Klug. Természetrajzi Füzetek, vol. 21, p. 497-500.

MORATO, EF., 1994. Abundância e riqueza de machos de Euglossini (Hymenoptera: Apidae) em mata de terra firme e áreas de derrubada, nas vizinhanças de Manaus (Brasil). Boletim do Museu Paraense Emílio Goeldi. Zoologia, vol. 10, p. 95-105.

MOURE, JS., 1960. Notes on the types of Neotropical bees described by Fabricius (Hymenoptera: Apoidea). Studia Entomologica, vol. 3, p. 97-160.

MOURE, JS., 1968. Espécies novas de Euglossa da América Central. Boletim da Universidade Federal do Paraná. Zoologia, vol. 3, p. 13-64.

MOURE, JS., 1969. The central american species of Euglossa subgenus Glossura Cockerell, 1917 (Hymenoptera, Apidae). Revista de Biologia Tropical, vol. 15, p. 227-247.

MOURE, JS., 1970. The species of euglossine bees of Central América belonging to the subgenus Euglossella. Anais da Academia Brasileira de Ciencias, vol. 42, p. 148-157.

MOURE, JS., 1996. (“1995”) Notas sobre algumas espécies de abelhas da Bahia, Brasil (Hymenoptera, Apoidea). Revista Brasileira de Zoologia, vol. 12, p. 467-470.

NEMÉSIO, A., 2009. Orchid bees (Hymenoptera: Apidae) of the Brazilian Atlantic Forest. Zootaxa, vol. 2041, p. 1-242.

NEMÉSIO, A., 2010. The orchid-bee fauna (Hymenoptera: Apidae) of a forest remnant in northeastern Brazil, with new geographic records and an identification key to the known species of the Atlantic Forest of northeastern Brazil. Zootaxa, vol. 2656, p. 55-66.

NEMÉSIO, A., 2011a. The orchid-bee fauna (Hymenoptera: Apidae) of a forest remnant in southern Bahia, Brazil, with new geographic records and an identification key to the known species of the area. Zootaxa, vol. 2821, p. 47-54.

NEMÉSIO, A., 2011b. Euglossa marianae sp. n. (Hymenoptera: Apidae): a new orchid bee from the Brazilian Atlantic Forest and the possible first documented local extinction of a forest dependent orchid bee. Zootaxa, vol. 2892, p. 59-68.

NEMÉSIO, A., 2012. Methodological concerns and challenges in ecological studies with orchid bees (Hymenoptera: Apidae: Euglossina). Bioscience Journal, vol. 28, p. 118-134.

NEMÉSIO, A., CERÂNTOLA, NCM., VASCONCELOS, HL., NABOUT, JC., SILVEIRA, FA. and DEL LAMA, MA., 2012. Searching for Euglossa cyanochlora Moure, 1996 (Hymenoptera: Apidae), one of the rarest bees in the world. Journal of Insect Conservation, vol. 16, no. 5, p. 745-755. http://dx.doi.org/10.1007/ s10841-012-9459-2.

NEMÉSIO, A. and FERRARI, RR., 2012. The species of Eulaema (Eulaema) Lepeletier, 1841 (Hymenoptera: Apidae: Euglossina) from eastern Brazil, with description of Eulaema quadragintanovem sp. n. from the state of Ceará. Zootaxa, vol. 3478, p. 123-132.

NEMÉSIO, A. and MORATO, EF., 2004. Euglossina (Hymenoptera: Apidae: Apini) of the Humaitá Reserve, Acre state, Brazilian Amazon, with comments on bait trap efficiency. Revista de Tecnologia e Ambiente, vol. 10, p. 71-80.

NEMÉSIO, A. and MORATO, EF., 2006. The orchid-bee fauna (Hymenoptera: Apidae) of Acre state (northwestern Brazil) and a re-evaluation of euglossine bait-trapping. Lundiana, vol. 7, p. 59-64.

NEMÉSIO, A. and RASMUSSEN, C., 2011. Taxonomic issues in the orchid bees (Hymenoptera: Apidae: Euglossina), and an updated catalogue. Zootaxa, vol. 3006, p. 1-42.

NEMÉSIO, A. and SILVEIRA, FA., 2004. Biogeographic notes on rare species of Euglossina (Hymenoptera: Apidae: Apini) occurring in the Brazilian Atlantic Rain Forest. Neotropical 
Entomology, vol. 33, no. 1, p. 117-120. http://dx.doi.org/10.1590/ S1519-566X2004000100021.

NEMÉSIO, A. and SILVEIRA, FA., 2006a. Deriving ecological relationships from geographical correlations between host and parasitic species: an example with orchid bees. Journal of Biogeography, vol. 33, no. 1, p. 91-97. http://dx.doi.org/10.1111/ j.1365-2699.2005.01370.x.

NEMÉSIO, A. and SILVEIRA, FA., 2006b. Edge effects on the orchid-bee fauna (Hymenoptera: Apidae) at a large remnant of Atlantic Rain Forest in southeastern Brazil. Neotropical Entomology, vol. 35, no. 3, p. 313-323. http://dx.doi.org/10.1590/ S1519-566X2006000300004. PMid:18575690

NEMÉSIO, A. and SILVEIRA, FA., 2006c. First record of Eulaema helvola Moure (Hymenoptera: Apidae: Euglossina) for the State of Minas Gerais: biogeographic and taxonomic implications. Neotropical Entomology, vol. 35, no. 3, p. 418-420. http://dx.doi. org/10.1590/S1519-566X2006000300021. PMid:18575707

NEMÉSIO, A. and SILVEIRA, FA., 2007a. Orchid bee fauna (Hymenoptera: Apidae: Euglossina) of Atlantic Forest fragments inside an urban area in southeastern Brazil. Neotropical Entomology, vol. 36, no. 2, p. 186-191. http://dx.doi.org/10.1590/S1519566X2007000200003. PMid:17607450

NEMÉSIO, A. and SILVEIRA, FA., 2007b. Diversity and distribution of orchid bees (Hymenoptera: Apidae) with a revised checklist of species. Neotropical Entomology, vol. 36, no. 6, p. 874-888. http://dx.doi.org/10.1590/S1519-566X2007000600008. PMid: 18246261

NEMÉSIO, A. and SILVEIRA, FA., 2010. Forest fragments with larger core areas better sustain diverse orchid bee faunas (Hymenoptera: Apidae: Euglossina). Neotropical Entomology, vol. 39, no. 4, p. 555-561. http://dx.doi.org/10.1590/S1519566X2010000400014. PMid:20877991

OLIVEIRA, ML., 2006. Três novas espécies de abelhas da Amazônia pertencentes ao gênero Eulaema (Hymenoptera: Apidae: Euglossini). Acta Amazonica, vol. 36, no. 1, p. 121-127. http:// dx.doi.org/10.1590/S0044-59672006000100015.

OLIVEIRA, ML. and CAMPOS, LAO., 1996. Preferência por estratos florestais e por substâncias odoríferas em abelhas Euglossinae (Hymenoptera, Apidae). Revista Brasileira de Zoologia, vol. 13, no. 4, p. 1075-1085. http://dx.doi.org/10.1590/ S0101-81751996000400025.

OLIVIER, GA., 1789. Abeille. In: OLIVIER, GA. (Ed.). [Encyclopédie méthodique, ou par ordre de matières; par une société de gens de lettres, de savants et d'artistes] Encyclopédie méthodique, histoire naturelle, insectes. Paris: Panckoucke, Plomteux. p. 46-84.

PACKARD, AS., 1869. List of hymenopterous and lepidopterous insects collected by the Smithsonian expedition to South America, under Prof. James Orton. Annual Report of the Trustees of the Peabody Academy of Science, vol. 1, p. 56-69.

PEARSON, DL. and DRESSLER, RL., 1985. Two-year study of male orchid bee (Hymenoptera: Apidae: Euglossini) attraction to chemical baits in lowland south-eastern Perú. Journal of Tropical Ecology, vol. 1, no. 01, p. 37-54. http://dx.doi.org/10.1017/ S0266467400000067.

PIELOU, EC., 1975. Ecological diversity. New York: John Wiley $\&$ Sons. $165 \mathrm{p}$.
POWELL, AH. and POWELL, GVN., 1987. Population dynamics of male euglossine bees in Amazonian forest fragments. Biotropica, vol. 19, no. 2, p. 176-179. http://dx.doi.org/10.2307/2388742.

RAMÍREZ, S., DRESSLER, RL. and OSPINA, M., 2002. Abejas Euglosina (Hymenoptera: Apidae) de la región neotropical: listado de espécies con notas sobre su biología. Biota Colombiana, vol. 3 , p. 7-118

RAMÍREZ, SR., ROUBIK, DW., SKOV, C. and PIERCE, NE., 2010. Phylogeny, diversification patterns and historical biogeography of euglossine orchid bees (Hymenoptera: Apidae). Biological Journal of the Linnean Society. Linnean Society of London, vol. 100, no. 3, p. 552-572. http://dx.doi.org/10.1111/j.1095-8312.2010.01440.x.

RASMUSSEN, C., 2009. Diversity and abundance of orchid bees (Hymenoptera: Apidae, Euglossini) in a tropical rainforest succession. Neotropical Entomology, vol. 38, no. 1, p. 812-9. http:// dx.doi.org/10.1590/S1519-566X2009000100006. PMid:19347098

RASMUSSEN, C. and SKOV, C., 2006. Description of a new species of Euglossa (Hymenoptera: Apidae: Euglossini) with notes on comparative biology. Zootaxa, vol. 1210, p. 53-67.

ROUBIK, DW., 2004a. Long-term studies of solitary bees: what the orchid bees are telling us. In Freitas, BM. and Pereira, JO. (Eds.). Solitary bees? Conservation, rearing, management for pollination. Fortaleza: Imprensa Universitária. p. 97-103.

ROUBIK, DW., 2004b. Sibling species among Glossura and Glossuropoda in the Amazon region (Hymenoptera: Apidae: Euglossini). Journal of the Kansas Entomological Society, vol. 77, no. 3, p. 235-253. http://dx.doi.org/10.2317/0308.20.1

SMITH, F., 1854. Catalogue of the Hymenopterous insects in the collection of the British Museum. Part II, Apidce. London: British Museum (Natural History). 267 p.

SMITH, F., 1874. A revision of the genera Epicharis, Centris, Eulema and Euglossa, belonging to the family Apidae, section Scopulipedes. Annals \& Magazine of Natural History, vol. 13, no. 78, p. 440-446. http://dx.doi.org/10.1080/00222937408680899.

SNEATH, PHA. and SOKAL, RR., 1973. Numerical taxonomy: the principles and practice of numerical classification. San Francisco: Freeman and Co. 573 p.

STORCK-TONON, D., MORATO, EF. and OLIVEIRA, ML., 2009. Fauna de Euglossina (Hymenoptera: Apidae) da Amazônia Sul-Ocidental, Acre, Brasil. Acta Amazonica, vol. 39, no. 3, p. 693-706. http://dx.doi.org/10.1590/S0044-59672009000300026.

STORCK-TONON, D., SILVA, MV. and MORATO, EF., 2011. Checklist of orchid bees (Hymenoptera: Apidae) of "Lago do Silêncio" area, Boca do Acre, Amazonas, Brazil. Check List, vol. 7, p. 648-651

VOGEL, S., 1966. Parfümsammelnde Bienen als Bestäuber von Orchidaceen und Gloxinia. Österreiches. Botanicheskii Zhurnal, vol. 113 , p. 302-361.

WESTWOOD, JO., 1840. Entomology [Vol. 6]. Bees, comprehending the uses and economical management of the honey-bee of Britain and other countries, together with descriptions of the known wild species. In JARDINE, W. (Ed.). The naturalist's library. Edinburgh: W.H. Lizars. p. viii+17-301, 30 pls.

WOLDA, H., 1981. Similarity indices, sample sizes and diversity. Oecologia, vol. 50, no. 3, p. 296-302. http://dx.doi.org/10.1007/ BF00344966. 